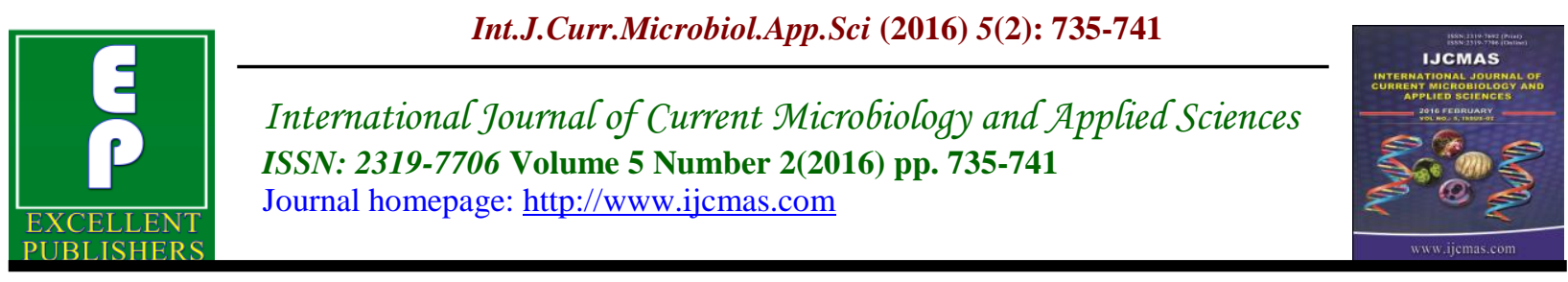

Original Research Article

doi: http://dx.doi.org/10.20546/ijcmas.2016.502.082

\title{
Assessment of Microbial Contamination of Paper Currency Notes in Circulation
}

\author{
G. Sucilathangam*, Ajay Mal Reventh, G. Velvizhi and C. Revathy \\ Department of Microbiology, Tirunelveli Medical College, \\ Tirunelveli - 627 011, Tamil Nadu, India \\ *Corresponding author
}

\begin{abstract}
A B S T R A C T
Keywords

Indian paper

currency,

Escherichia coli,

Staphylococcus

aureus,

Pathogenic

Microorganisms,

Contamination.

Article Info

Accepted:

28 January 2016

Available Online:

10, February 2016

Money, whether in the form of coins or paper notes is perhaps the most widely handled article by people everyday throughout the world. Money is used as a medium for exchange for goods and services, settlement of debts and for deferred payments in economic activities. Currency notes represent a universal medium for the transmission of bacteria in the environment and among humans. There is a possibility that currency notes might act as environmental vehicles for the transmission of pathogenic organisms. This prospective study, which was carried out for a period of two months in a tertiary care hospital. The present investigation was carried out on one hundred and twenty Indian paper currency notes of all the denominations obtained from different occupational groups in Tirunelveli City, TamilNadu, India. $86.4 \%$ of currencies were contaminated with pathogenic organisms. 121 isolates from the collected Indian paper currency yielded 6 different types of bacterial species. Assessment revealed active participation of the following organisms as Escherichia coli, Bacillus spp, Klebsiella spp, Staphylococcus aureus,Micrococci and Pseudomonas spp. Rs.100, Rs.50 had more contamination, other denominations like Rs.5, Rs.10, Rs.20 had moderate contamination and less contamination with Rs.500 and Rs.1000.. The study suggested that Indian paper currency notes are highly contaminated with pathogenic microorganisms and this contamination may play a significant role in transmission of infectious diseases. Hence, great care must be taken while handling money during the preparation and handling of food to avoid cross contamination.
\end{abstract}

\section{Introduction}

Globally, money is one of the items most frequently passed from hand to hand. During its passing, money can get contaminated and may thus play a role in the transmission of microorganisms to other people.

For example, money may get contaminated with microorganisms from the respiratory and gastro-intestinal tract during counting.
Money is not usually suitable for the survival of microorganisms, except for some that are resistant to external conditions and non-resistant forms of spores.[1,2]In addition, the general hygiene levels of a community or society may contribute to the amount of microbes found on coins and notes, and thus the chance of transmission during handling of money. 
Indian paper currency is commonly contaminated with pathogenic bacteria and this contamination may play a significant role in the transmission of different diseases. People and government are relevant about spread of pathogens through food, air, water and have taken enough steps to control it. But, they are not aware about the possibility of acquiring infection while applying saliva on fingers for counting currency notes which are widely exchanged from hand to hand represents a universal medium for transmission of microbes in the environment and among humans.

Antimicrobial resistance is a global phenomenon that has resulted in high morbidity and mortality as a result of treatment failures and increased health care costs.[3]While antimicrobial resistance has steadily been increasing, e.g. with ExtendedSpectrum Beta Lactamases (ESBL) producing Escherichia coli and Klebsiella spp contaminated banknotes and coins contribute to the transmission of these multidrug resistant microorganisms in the community.[4]

In India, few studies have reported the microbial colonization of currency. Studies of the contamination of money with microbial agents is lacking in Southern Tamil Nadu. Knowledge of the microbial diversity of currency notes in circulation can provide the basis for raise health consciousness in people during currency handling and effective control of infection transmission. Hence, the present study was undertaken to identify microbial contamination of Indian currency notes in circulation and to study the antibiotic susceptibility pattern of the pathogenic isolates.

\section{Materials and Methods}

\section{Study Area and Design}

The study was conducted in different parts of Tirunelveli, TamilNadu, India where various Indian currency denominations were randomly collected from everyday use from March 2014 to August 2014 and processing of samples were done at Microbiology Department, Tirunelveli Medical College Hospital. The study protocol was approved by the Institutional Scientific and Ethics Committee.

\section{Sample Collection}

A total of 140 paper currency notes consisting of Twenty notes of each of INR.5, INR.10, INR.20, INR.50, INR.100, INR.500 and INR.1000 denominations were collected from Doctors, various shops of vegetable, fruit, spices selling and slaughter house aseptically. To collect the paper currency, the individual were requested to drop currency notes into a sterile polythene bag and labelled accordingly; notes were not touched by the researcher using bare hands at any stage. The packet was sealed and immediately transported to the laboratory for analysis.30 more new currency notes were collected from the bank as control samples.

\section{Laboratory Methods and Procedures}

All laboratory works were undertaken in the Microbiology laboratory.

\section{Identification and Isolation of Microbes}

Sterile cotton swab was dipped in the sterile distilled water and was rubbed on both the surfaces of currency notes and then to inoculate onto the culture plates for each note. The plates were incubated at $37^{\circ} \mathrm{C}$ for 24 hours. Then the plates were observed for bacterial colonies. Pure isolated colonies were Gram differentiated and then biochemically identified using Indole, Catalase, Citrate, Oxidase, Coagulase, and Urease tests. 


\section{Antibiotic Susceptibility Test (AST)}

Antibiotic susceptibility was determined by the agar diffusion technique on MuellerHinton agar (Kirby-Bauer NCCLS modified disc diffusion technique) using 9 antibiotic discs including Ampicillin $(10 \mu \mathrm{g})$, Amikacin (30 $\mu \mathrm{g}), \quad$ Gentamicin $(10 \mu \mathrm{g})$, Cotrimoxazole $(25 \mu \mathrm{g})$, Cefotaxime $(30 \mu \mathrm{g})$, Ceftazidime $(30 \mu \mathrm{g})$, Ceftriaxone $(30 \mu \mathrm{g})$, Ciprofloxacin $(5 \mu \mathrm{g})$ and Erythromycin $(5 \mu \mathrm{g})$.

\section{Results and Discussion}

The paper currency notes are graded using condition, appearance and degree of dirtiness as new, moderate and old as shown in Table 1. The present study revealed the extent and the level of microbial contamination of Indian paper currency. $86.4 \%$ of currencies were contaminated with pathogenic organisms. 121 isolates from the collected Indian paper currency yielded 6 different types of bacterial species. Identification showed the active participation of these species in descending order as, Klebsiella spp, Bacillus spp, Escherichia coli, Pseudomonas spp, Micrococci and Staphylococcus aureus. The frequency of occurrence of Klebsiella spp was the highest in the present study which indicates the presence of faecal contamination via cross-contamination with raw products or poor personal hygiene.

Table 2 shows the prevalence occurrence of pathogenic microorganisms isolated from Indian paper currency notes from different occupational groups mainly fish seller, meat

Seller, vegetable seller, Doctors. The results showed in Table 3 indicated that all the currency denominations groups had microbial contamination and Rs.100, Rs.50 had more contamination, other denominations like Rs.5, Rs.10, Rs.20 had moderate contamination and less contamination with Rs.500 and Rs.1000. These lower denominations are used frequently for different normal daily activities. Higher denominations are not used as frequently as lower denominators. Smaller unit notes appeared to be more highly contaminated than larger unit notes, probably because the smaller unit notes are most frequently handled in petty, daily monetary transactions and are often tattered, dirty.

Resistance pattern of all pathogenic Gram negative bacilli and Gram positive organisms were given in Table 4. Only one isolate of Staphylococcus aureus was MRSA and All the Gram negative bacilli were resistant to Ampicillin.11 strains of $E$. coli and 49 strains of Klebsiella were resistant to Ampicillin. These two bacteria were found to be quite sensitive to Amikacin, Gentamicin and Ciprofloxacin. Klebsiella were more resistant to different cephalosporin groups whereas E.coli was less resistant. Pseudomonas was quite sensitive to Amikacin, Gentamicin, Ciprofloxacin and cephalosporins.

The present study collected the notes from various sources such as fish seller, meat Seller, vegetable seller, Doctors, local markets and banks which are in accordance with the previous studies [5-8] $86.4 \%$ of the notes analyzed were found to be contaminated with pathogenic organisms. Extent of contamination was found related to the denominations of the currency. Currency notes of lower denominations (Rs.5, Rs.10, 20, 50,100) were the most contaminated than higher denominations (Rs.500, Rs.1000) and this is consistent with previous studies.[5,9]This is expected, as lower denomination notes pass through more hands than the higher denomination during petty, daily monetary transactions and are often tattered, dirty. 
The present study suggests that currency notes may carry enteric pathogens. This goes a long way to reveal the poor sanitary condition of the environment as well as poor personal hygiene practices observed by most of the occupational groups. Goktas and Oktay (1992) found similar result as present investigation. They isolated aerobic spore forming bacilli (91\%), Staphylococcus epidermidis (63.3\%),Staphylococcus aureus
(4.2\%), Enterococcus (24.1\%), alpha haemolytic streptococcus (4.1\%), Streptococcus pneumonia (1.7\%), Corynebacterium (7.5\%), Lactobacilli (10.8\%), Klebsiella pneumoniae (31.7\%), Enterobacter (19.2\%), E. coli (17.5\%),Proteus (1.7\%), Pseudomonas aeruginosa (0.8\%), Shigella flexneri $(0.8 \%)$ from paper money samples of one hundred twenty currency notes.[10]

Table.1 Physical Condition of Indian Paper Currency Notes Collected From Different Occupational Groups

\begin{tabular}{|c|c|c|c|c|}
\hline & OLD & MODERATE & NEW & TOTAL \\
\hline INR 5 & 12 & 6 & 2 & 20 \\
\hline INR 10 & 5 & 8 & 7 & 20 \\
\hline INR 20 & 7 & 7 & 6 & 20 \\
\hline INR 50 & 7 & 9 & 4 & 20 \\
\hline INR 100 & 8 & 6 & 6 & 20 \\
\hline INR 500 & 5 & 7 & 8 & 20 \\
\hline INR 1000 & 3 & 8 & 9 & 20 \\
\hline TOTAL & 47 & 51 & 42 & 140 \\
\hline
\end{tabular}

Table.2 Source of Microbial Isolates in Indian Currency Notes

\begin{tabular}{|l|c|c|c|c|c|c|c|c|}
\hline & $\begin{array}{c}\text { E.coli } \\
\text { spp }\end{array}$ & $\begin{array}{c}\text { Kleb } \\
\text { siella } \\
\text { spp }\end{array}$ & $\begin{array}{c}\text { Pseudo } \\
\text { monas spp }\end{array}$ & $\begin{array}{c}\text { Micro } \\
\text { cocci spp }\end{array}$ & $\begin{array}{c}\text { Staphylococc } \\
\text { us spp }\end{array}$ & $\begin{array}{c}\text { Bacillus } \\
\text { spp }\end{array}$ & $\begin{array}{c}\text { No } \\
\text { growth }\end{array}$ & Total \\
\hline Doctors & 2 & 4 & 1 & 0 & 0 & 1 & 3 & 11 \\
\hline Vegetable vendor & 3 & 9 & 2 & 3 & 1 & 7 & 5 & 30 \\
\hline Fish vendor & 2 & 4 & 0 & 0 & 0 & 1 & 1 & 8 \\
\hline Butchers & 2 & 4 & 0 & 0 & 0 & 0 & 1 & 7 \\
\hline Banks & 1 & 5 & 0 & 2 & 0 & 2 & 3 & 13 \\
\hline Bus conductor & 0 & 7 & 2 & 1 & 0 & 3 & 7 & 20 \\
\hline Student & 0 & 8 & 0 & 0 & 0 & 0 & 0 & 8 \\
\hline Hotel & 2 & 2 & 0 & 1 & 0 & 2 & 0 & 7 \\
\hline Bike spares vendor & 1 & 8 & 0 & 0 & 0 & 0 & 5 & 14 \\
\hline Lab technician & 0 & 1 & 0 & 0 & 0 & 0 & 14 & 15 \\
\hline House wife & 0 & 5 & 0 & 0 & 0 & 2 & 0 & 7 \\
\hline \multicolumn{1}{|c|}{ Total } & 13 & 57 & 5 & 7 & 1 & 18 & 39 & 140 \\
\hline
\end{tabular}


Table.3 Percentage of Bacterial Genus Isolated from Indian Currency Notes in Circulation

\begin{tabular}{|c|c|c|c|c|c|c|c|c|}
\hline & $\begin{array}{l}\text { E.coli } \\
\text { spp }\end{array}$ & $\begin{array}{l}\text { Klebsella } \\
\text { Spp }\end{array}$ & $\begin{array}{l}\text { Pseudomonas } \\
\text { Spp }\end{array}$ & $\begin{array}{l}\text { Micrococci } \\
\text { Spp }\end{array}$ & $\begin{array}{l}\text { Staphylococcus } \\
\text { Spp }\end{array}$ & $\begin{array}{l}\text { Bacillus } \\
\text { Spp }\end{array}$ & $\begin{array}{l}\text { No } \\
\text { Growth }\end{array}$ & Total \\
\hline $\begin{array}{c}\text { INR } \\
5 \\
\end{array}$ & $\begin{array}{c}1 \\
(7 \%)\end{array}$ & $\begin{array}{c}\mathbf{4} \\
(7 \%) \\
\end{array}$ & $\begin{array}{c}1 \\
(20 \%) \\
\end{array}$ & $\begin{array}{c}\mathbf{0} \\
(0 \%) \\
\end{array}$ & $\begin{array}{c}\mathbf{0} \\
(0 \%) \\
\end{array}$ & $\begin{array}{c}\mathbf{6} \\
(33.3 \%) \\
\end{array}$ & $\begin{array}{c}\mathbf{8} \\
(20.5 \%) \\
\end{array}$ & 20 \\
\hline $\begin{array}{c}\text { INR } \\
10 \\
\end{array}$ & $\begin{array}{c}1 \\
(7 \%) \\
\end{array}$ & $\begin{array}{c}\mathbf{1 0} \\
(17.5 \%)\end{array}$ & $\begin{array}{c}\mathbf{2} \\
(40 \%) \\
\end{array}$ & $\begin{array}{c}\mathbf{0} \\
(0 \%) \\
\end{array}$ & $\begin{array}{c}1 \\
(100 \%) \\
\end{array}$ & $\begin{array}{c}\mathbf{0} \\
(0 \%) \\
\end{array}$ & $\begin{array}{c}\mathbf{6} \\
(15.4 \%) \\
\end{array}$ & 20 \\
\hline $\begin{array}{c}\text { INR } \\
20\end{array}$ & $\begin{array}{c}\mathbf{3} \\
(23 \%)\end{array}$ & $\begin{array}{c}\mathbf{6} \\
(10.5 \%)\end{array}$ & $\begin{array}{c}1 \\
(20 \%)\end{array}$ & $\begin{array}{c}\mathbf{1} \\
(14.3 \%)\end{array}$ & $\begin{array}{c}\mathbf{0} \\
(0 \%)\end{array}$ & $\begin{array}{c}1 \\
(5.5 \%)\end{array}$ & $\begin{array}{c}\mathbf{8} \\
(20.5 \%)\end{array}$ & 20 \\
\hline $\begin{array}{c}\text { INR } \\
50\end{array}$ & $\begin{array}{c}\mathbf{4} \\
(30 \%)\end{array}$ & $\begin{array}{c}\mathbf{6} \\
(10.5 \%)\end{array}$ & $\begin{array}{c}1 \\
(20 \%)\end{array}$ & $\begin{array}{c}\mathbf{1} \\
(14.3 \%)\end{array}$ & $\begin{array}{c}\mathbf{0} \\
(0 \%)\end{array}$ & $\begin{array}{c}\mathbf{6} \\
(33.3 \%) \\
\end{array}$ & $\begin{array}{c}2 \\
(5.1 \%)\end{array}$ & 20 \\
\hline $\begin{array}{r}\text { INR } \\
100 \\
\end{array}$ & $\begin{array}{c}2 \\
(15 \%) \\
\end{array}$ & $\begin{array}{c}\mathbf{1 6} \\
(28 \%) \\
\end{array}$ & $\begin{array}{c}\mathbf{0} \\
(0 \%) \\
\end{array}$ & $\begin{array}{c}\mathbf{0} \\
(0 \%) \\
\end{array}$ & $\begin{array}{c}\mathbf{0} \\
(0 \%) \\
\end{array}$ & $\begin{array}{c}1 \\
(5.5 \%) \\
\end{array}$ & $\begin{array}{c}1 \\
(2.7 \%) \\
\end{array}$ & 20 \\
\hline $\begin{array}{l}\text { INR } \\
500 \\
\end{array}$ & $\begin{array}{c}2 \\
(15 \%) \\
\end{array}$ & $\begin{array}{c}7 \\
(12.2 \%) \\
\end{array}$ & $\begin{array}{c}\mathbf{0} \\
(0 \%) \\
\end{array}$ & $\begin{array}{c}\mathbf{2} \\
(28.5 \%) \\
\end{array}$ & $\begin{array}{c}\mathbf{0} \\
(0 \%) \\
\end{array}$ & $\begin{array}{c}2 \\
(11.1 \%) \\
\end{array}$ & $\begin{array}{c}7 \\
(17.9 \%) \\
\end{array}$ & 20 \\
\hline $\begin{array}{l}\text { INR } \\
1000 \\
\end{array}$ & $\begin{array}{c}\mathbf{0} \\
(0 \%) \\
\end{array}$ & $\begin{array}{c}\mathbf{8} \\
(14 \%) \\
\end{array}$ & $\begin{array}{c}\mathbf{0} \\
(0 \%) \\
\end{array}$ & $\begin{array}{c}3 \\
(42.9 \%) \\
\end{array}$ & $\begin{array}{c}\mathbf{0} \\
(0 \%) \\
\end{array}$ & $\begin{array}{c}2 \\
(11.1 \%) \\
\end{array}$ & $\begin{array}{c}7 \\
(17.9 \%) \\
\end{array}$ & 20 \\
\hline Total & $\begin{array}{c}13 \\
(9.2 \%) \\
\end{array}$ & $\begin{array}{c}57 \\
(40.7 \%) \\
\end{array}$ & $\begin{array}{c}\mathbf{5} \\
(3.8 \%) \\
\end{array}$ & $\begin{array}{c}7 \\
(5 \%) \\
\end{array}$ & $\begin{array}{c}1 \\
(0.7 \%) \\
\end{array}$ & $\begin{array}{c}18 \\
(12.9 \%)\end{array}$ & $\begin{array}{c}39 \\
(27.9 \%)\end{array}$ & $\begin{array}{c}140 \\
(100 \%)\end{array}$ \\
\hline
\end{tabular}

Table.4 Antibiotic Sensitivity Pattern of Microbes isolated from Indian Currency Notes

\begin{tabular}{|c|c|c|c|c|c|c|c|c|c|c|c|c|c|c|c|c|}
\hline & \multicolumn{2}{|c|}{ AMP } & \multicolumn{2}{|c|}{ AMI } & \multicolumn{2}{|c|}{ GN } & \multicolumn{2}{|c|}{ CIPRO } & \multicolumn{2}{|c|}{ CTZ } & \multicolumn{2}{|c|}{ CFX } & \multicolumn{2}{|c|}{ DOXY } & \multicolumn{2}{|c|}{ CFTZ } \\
\hline & $\mathbf{S}$ & $\mathbf{R}$ & $\mathbf{S}$ & $\mathbf{R}$ & $\mathbf{S}$ & $\mathbf{R}$ & $\mathbf{S}$ & $\mathbf{R}$ & $\mathbf{S}$ & $\mathbf{R}$ & $\mathbf{S}$ & $\mathbf{R}$ & $\mathbf{S}$ & $\mathbf{R}$ & $\mathbf{S}$ & $\mathbf{R}$ \\
\hline E.coli spp & 10 & 3 & 11 & 2 & 13 & $\mathbf{0}$ & 12 & 1 & 12 & 1 & 11 & 2 & 12 & 1 & 11 & 2 \\
\hline Klebsiella spp & 40 & 17 & 49 & 8 & 52 & 5 & 55 & 3 & 45 & 12 & 46 & 11 & 55 & 2 & 44 & 13 \\
\hline $\begin{array}{l}\text { Pseudomonas } \\
\text { spp }\end{array}$ & 2 & 3 & 3 & 2 & 4 & 1 & 5 & $\mathbf{0}$ & 5 & $\mathbf{0}$ & 4 & 1 & 4 & 1 & 3 & 2 \\
\hline Micrococci spp & 3 & 4 & 5 & 2 & 4 & 3 & 6 & $\mathbf{1}$ & 5 & 2 & 4 & 3 & 5 & 2 & 3 & 4 \\
\hline Bacillus spp & 11 & 7 & 6 & 12 & 10 & 8 & 15 & 3 & 18 & $\mathbf{0}$ & 12 & 6 & 15 & 3 & 12 & 6 \\
\hline $\begin{array}{l}\text { Staphylococcus } \\
\text { spp }\end{array}$ & $\mathbf{0}$ & $\mathbf{1}$ & $\mathbf{0}$ & 1 & $\mathbf{0}$ & $\mathbf{1}$ & 1 & $\mathbf{0}$ & $\mathbf{0}$ & 1 & $\mathbf{0}$ & 1 & 1 & $\mathbf{0}$ & $\mathbf{0}$ & 1 \\
\hline Total & 66 & 35 & 74 & 27 & 84 & 17 & 93 & 8 & 85 & 16 & 77 & 24 & 92 & 9 & 73 & 28 \\
\hline
\end{tabular}

AMP- AMPICILLIN; AMI- AMIKACIN; GN-GENTAMICIN; CIPRO- CIPROFLOXACIN; CTZ- CEFTAZIDIME; CFXCEFOTAXIME; DOXY- DOXYCYCLINE; CFTZ- C EFTRIAXONE; S- SENSITIVITY; R- RESISTANT

The frequency of occurrence of Klebsiella pneumoniae was the highest in the present study $(40.7 \%)$ which indicates the presence of faecal contamination via cross- contamination with raw products or poor personal hygiene. Common unhygienic practices in the open-air markets in rural areas, where traders and buyers eat market 
products after handling contaminated currency notes, may place the individuals at risk of ingesting enteropathogens. [5] In contrast, isolation of $E$. coli was only $9.2 \%$ which are in accordance with the previous studies. [8, 11]The other isolates found in the present study were Staphylococcus aureus $(0.7 \%)$ and Pseudomonas aeruginosa $(3.8 \%)$ which is lower than the previous reports. $[7,8]$

Currency notes in general were bacteriologically contaminated, especially with enteric pathogens and potentially pathogens, it was thought that some measures have to be taken to reduce these ill effects. Among the pathogenic bacteria isolated, Escherichia coli is a virulent organism that can cause urinary tract infections, community-acquired pneumonia, sepsis, recurrent meningitis.[12,13] Klebsiella spp can cause fatal acute bacterial myocarditis, pneumonia, meningitis and wound Infections.[14,15]

A number of studies have documented the clinical significance of Staphylococcus aureus as a causative agent of urinary tract infections.[16] Furthermore, Staphylococcus aureus is also associated with toxic shock syndrome, skin infections and respiratory tract infections.[17,18]These microorganisms can cause cholera, diarrhoea and urinary tract infections besides skin bum and septicaemia infections.

Money has got the potential to change through many different hands and could be exposed to many different environments at a relatively high frequency. From the results of the present investigation, it is concluded that Indian paper currency is commonly contaminated with pathogenic bacteria and this contamination may play a significant role in the transmission of different diseases. We therefore advocate a greater sensitivity in the handling of money. The general awareness about the possibility of acquiring infection while applying saliva on fingers for counting currency notes; and practicing good personal hygiene should be created in the public. Personal hygiene to reduce risk of infection is recommended especially for those who simultaneously handle food and money.

\section{Acknowledgement}

The authors are gratefully acknowledge The Dean, Tirunelveli Medical College Hospital, Tirunelveli, Tamil Nadu and The Staff of Microbiology of Tirunelveli Medical College Hospital.

\section{References}

1. Freeman BA: Burrows Textbook of Microbiology. 22nd edition. Philadelphia: WB Saunders Co; 1985.

2. Jawetz E, Melnick JL, Adelberg EA: Review of Microbiology. California: Lange Pub; 1987.

3. Laxminarayan R, Malani A. Extending the Cure: Policy responses to the growing threat of antibiotic resistance. Washington, DC, Resources for the Future.

4. Gedik H, Yahyaoğlu M, Yörük G, Fincanc1 M.Extended-Spectrum BetaLactamase production Rates of Klebsiella spp. and Escherichia coli strains Isolated from infections and faecal samples of healthy people. Infectious Diseases in Clinical Practice 2010; 18:104-106.

5. Igumbor E, Obi C, Bessong $\mathrm{P}$, Potgieter $\mathrm{N}$, Mkasi T. Microbiological analysis of banknotes circulating in the Venda region of Limpopo province, South Africa. S Afr j sci2007;103:9-10.

6. OO K, Win $\mathrm{P}$, Han A, Aye $\mathrm{T}$. Contamination of currency notes with 
enteric bacterial pathogens. Diarrhoeal Diseases Research: 92-4.

7. Pope T, Ender P, Woelk W, Koroscil M, Koroscil T. Bacterial contamination of paper currency. Southern Medical Journal2002; 95(12):1408-10.

8. Singh D, Thakur K. Microbiological surveillance of currency. Indian Journal of Medical Microbiology2002; 20(1):535.

9. Basavarajappa K, Rao P, Suresh K. Study of bacterial, fungal, and parasitic contamination of currency notes in circulation. Indian Journal of Pathology \& Microbiology2005; 48(2):278-9.

10. Goktas, RT. and Oktay, AD. Bacteriological examination of paper money. Mikrobiol. Bull 1992; 26: 344348.

11. Uneke C, Ogbu O. Potential for parasite and bacterial transmission by paper currency in Nigeria. Journal of Environmental Health 2007; 69(9):54.

12. Jayaseelan S., Young SK., Fessler MB., Liu Y,Malcom, KC, Yamamato $\mathrm{M}$ et al. Tol1/IL-1 receptor domain containing adaptor including IFN beta (TRIF)mediated signaling contributes to innate immune responses in the lung during Escherichia coli pneumonia. J.Immunol 2007; 178(5): 3153-3160.

13. Sun, HY, Chen, SY, Pan SC, Su CP, Chen, YC. Community onset Escherichia coli and Klebsiella pneumonia bacteraemia: influence of health care exposure on antimicrobial susceptibility. Diagn Microbiol Infect Dis 2006;55(2): 135-141.

14. Douglas SJ, Naomi, WJ, Charles TF, Victor AN. Rapidly fatal acute bacterial myocarditis in a nonneutropenic child with acute lymphoblastic leukaemia in remission. J.Pediatric Hematology Oncol . 2002; 24(8): 662-665.

15. Bentzel DE, Elliot TB, Keller CE, Brook I., Shoemaker MO, Knudson GB. Antimicrobial therapies for pulmonary Klebsiella pneumonia infection in B6D2F1/J mice immunocompromised by use of sub lethal irradiation. Comp. Med 2004; 54(2): 185-192.

16. Tessema, B., Kassu, A., Mulu, A. and Yeismaw, G. 2007.Predominant isolates of urinary tract pathogens and their antimicrobial susceptibility patterns in Gondar University Teaching Hospital, North West Ethiopia. Ethiop. Med., 45(1): 61-67.

17. Naidu, AS., Meidzobrodzki, J., Musser, JM., Rosdahl, VT., Hedstrom, SA, Forsgren A. Human lactoferrin binding in clinical isolates of Staphylococcus aureus. The J.Medical Microbiol 1991; 34(6): 323-328.

18. Miller, LG., Quan C., Shay A., Mostafaie, K., Bharadwa K., Tan, N. A prospective investigation of outcomes after hospital discharge for endemic, community acquired methicillin resisitant and susceptible Staphylococcus aureus skin infection. Clin. Infect. Dis 2007;44(4): 483-492.

\section{How to cite this article:}

Sucilathangam, G., Ajay Mal Reventh, G. Velvizhi and Revathy, C. 2016. Assessment of Microbial Contamination of Paper Currency Notes in Circulation. Int.J.Curr.Microbiol.App.Sci. 5(2): 735-741. doi: http://dx.doi.org/10.20546/ijcmas.2016.502.082 